\title{
Adolescents' Ambivalence of Premenstrual Dysphoric Disorder (PMDD): A Phenomenology Study
}

\author{
Dewi Marfuah \\ STIKEP PPNI JAWA BARAT \\ Correspondence: dewi.marfuah@yahoo.com
}

\begin{abstract}
Premenstrual Dysphoric Disorder (PMDD) is a form of menstrual disorder which is more severe than Premenstrual syndrome (PMS) with a prevalence of 3-8\%. The prevalence of PMDD increased in post-disaster about $41.8 \%$ and symptoms of PMDD affects the quality of women's lives. Objective: To describe adolescents' perception of PMDD symptoms. Methods A qualitative study used the phenomenological approach. The number of participants was six female students of SMK Negeri 1 Cangkringan that meet criteria of PMDD based on the Diagnostic and Statistic Manual of Mental Disorders (DSM-IV). The data were collected using In-depth interviews method with an unstructured interview. Colaizzi method was used for data analysis. Results: Two themes have emerged in this study which is; the positive perception: symptoms accepted as a natural phenomenon of women, and the negative perception: symptoms accepted as a disease. Conclusion: Adolescents' receptiveness of Premenstrual Dysphoric Disorder (PMDD) symptoms described in two themes: positive and negative perceptions. Nurses and other healthcare providers at healthcare institutions are expected to be more active in providing various kinds of health education especially about PMDD symptoms in adolescents that would be impacted their perceptions.
\end{abstract}

Keywords: Adolescent, ambivalence, premenstrual dysphoric disorder.

\section{INTRODUCTION}

Menstruation is the discharge of blood from the uterus through the vagina which happens monthly. Menstruation is a normal phenomenon in women's lives and a symbol of femininity and fertility (Jarrah, 2012). Premenstrual Dysphoric Disorder (PMDD) is a menstrual disorder which is more severe than PMS. The American College of Obstetricians and Gynecologists (ACOG) diagnose PMDD based on the prospective diarrhea symptoms which are shown about two months, and the symptoms also include physical,

physiological, and behavioral (Pakmehr \& Hagh, 2011).

The quality of life (Health-related quality

of life,) of women with premenstrual disorders were low and also found that they had severe mood disorders cycles during the luteal phase of the menstrual cycle, and it potentially degrades the quality of life (Perry et al., 2010).

The diagnosis of PMDD is based on the criteria of the Diagnostic and Statistic Manual of Mental Disorders (DSM-IV). This instrument assessed the PMDD by a 
retrospective approach from 5 days before menstruation until a few days after menstruation. Women had experienced five or more of the symptoms on the instrument, and there were symptoms about daily activities issues (work, study, relationships with family members, relationships with friends, and so forth) (Hapsari, 2006). The symptoms include anxiety, difficult to concentrate, suddenly feel sad or cry, easily offended, easy to feel tired, change in appetite (decrease or increase appetite), Sleep disorder (difficulty initiating sleep, difficulty maintaining sleep well, or need more sleep, Breast feels tight or distention of breast, Headache, Muscle or joint pain, Weight gain, Depression (feeling sad or feel no hope in the future), Decreased interest in routine activities (eg studying, hanging out with friends), easy to anger or irritability.

\section{METHODS}

The design of this study was a qualitative research with the phenomenological approach. The phenomenological method used in this research was the descriptive phenomenology. The research was conducted in SMK Negeri 1 Cangkringan in August to October 2014. The population in this study were 237 students. 6 students involved in the in-depth interviews and the interviews reached saturation of data.

The sample was chosen using the purposive sampling technique. The inclusion criteria were:

1. Have regular menstrual cycles during the past 3 months (21-35 days),

2. Meet the diagnostic criteria for PMDD with DSM - IV,

3. Willing to be a participant.

Exclusion criteria include:

1. Experiencing Post Traumatic Stress Disorder (PTSD)

2. Experiencing menstrual disorders other than PMDD, such as premenstrual syndrome (PMS), amenorrhoea, Oligomenorrhea, and polymenorrhea

3.

4. Consumption of illegal drugs or alcohol during the past 2 years.

The research had an ethical clearance test from the ethical committee of Medical Faculty in Gadjah Mada University with Nomor: S2/PSIK/653/M/01/01/04.14. Instruments in this study were the researcher who performs the in-depth interview with 
unstructured interview technique. The researcher also used the interview guide has been prepared. The tools were used during interviews such as field notes and voice recorder. The trustworthiness in this study used the source-triangulation with teachers and classmates.

The measuring instrument used for data collection in this study, among others; Criteria for diagnosis of PMDD according to the American College of Obstetricians and Gynecologies (ACOG) and the Diagnostic and Statistic Manual of Mental Disorders (DSM - IV) and the Impact of Event Scale-Revised (IES - R) were used to measure Post Traumatic Syndrome Disorder (PTSD). This questionnaire consists of 22 questions covering two symptoms of PTSD are flashbacks of events and avoidance of stimuli to measure the perceived distress in the last seven days associated with the traumatic event or disaster ever experience. The data were analyzed using the seven stages according to Colaizzi (Holloway \& Wheeler, 2010):

1) The researcher read all the transcripts of interviews.

2) Researcher read again the transcript of the participants many times to get the theme of experience symptoms of the premenstrual dysphoric disorder (PMDD).

3) Researcher deciphers the meanings of statements about the adolescent experience to formulate the meaning of these experiences that arise category.

4) Repeating every description and read the rest of the existing categories, comparing and finding similarities between these categories, and in the end grouping similar categories into sub-themes and themes.

5) Researcher combined the results of cluster theme obtained is then used to describe the phenomenon of adolescent perception with premenstrual dysphoric disorder symptoms (PMDD) is complete.

6) Formulate a complete description of the phenomenon (exhaustive description) into a clear statement or identify the essence of the adolescent perception.

7) The final stage is to validate the data that was collected by means of interviews.

\section{RESULTS}

\section{Overview Location of Research}

SMK N 1 Cangkringan is a vocational high school in the district of Sleman, Yogyakarta which are victims of Mount Merapi eruption in 2010, where all the buildings were badly damaged and destroyed by the eruption of Mount Merapi. This 
school is one of the first schools in the district Cangkringan which located closest to the peak of Merapi or in the danger zone $<10 \mathrm{~km}$. After the incident Merapi eruption in 2010, SMK N 1 Cangkringan relocated by the government to a safe area about 15 miles from Mount Merapi.

\section{Characteristics of Participants}

Six participants performed recording with In-depth Interviews. The characteristics of the participants are presented in table 1.

Table 1 the characteristics of the participants

\begin{tabular}{lc}
\hline \multicolumn{1}{c}{ Characteristics } & Percentage \\
\hline Age & \\
$14-16$ years & $2(33,3 \%)$ \\
$16-18$ years & $4(66,7 \%)$ \\
\hline Class & \\
X & $2(33,3 \%)$ \\
XI & $1(11,7 \%)$ \\
XII & $3(50 \%)$ \\
\hline Age of menarche & \\
$10-13$ years & $4(66,7 \%)$ \\
$13-15$ years & $2(33,3 \%)$ \\
\hline Home-School Distance & \\
$<5 \mathrm{~km}$ & 0 \\
$6-10 \mathrm{~km}$ & $4(66,7 \%)$ \\
$11-15 \mathrm{~km}$ & 0 \\
$16-20 \mathrm{~km}$ & $2(33,3 \%)$ \\
\hline
\end{tabular}

\section{The Results of Thematical Analysis}

The researcher found two themes of adolescent perception related symptoms of PMDD

namely the positive and negative perception.

a. Theme 1; Positive Perception: Symptoms Accepted as A Natural Phenomenon of Women.

The positive perception arises because they think that its symptoms are a habit and reasonable problem because it is seen as a natural phenomenon of a woman. Four participants exposed their perception about the symptoms which they felt as a natural condition of women, as it is conveyed participants as follows:

"Ya biasa aja gitu mbak, paling mau mens udah biasa kayak gitu mbak";

("yes,.......I feel usual, sister.... I think I will get menstruation, it is usually like that"..) 
"ya....wajar, ....hmm dah kodratnya wanita"

(yes, it just a reasonable problem,......hmm.... It is a natural condition of women”)

In addition, a positive perception showed by feelings of pleasure because the symptoms which they felt also felt by their friend so they perceived as a normal condition and indicates no disturbance or disease, as submitted by the participants as follows:

“...hmm....ya biasa aja...seneng aja...temen juga sama”; “...ya karna kalo gak mens itu kan ada..ada apa itu....gangguan gitu”.

(" ...hmm... just usual.......feel happy......my friends also like that", yes...because if not got menstruation ...it's mean....any something happened.......get a disease may be...")

\section{b. Theme 2; Negative Perception: Symptoms Accepted as A Disease}

Negative perception that participants conveyed was like as felt abnormal condition and not confident with peers because they felt that the symptoms were different from their friends. Two participants said that they felt abnormal because they assumed that normal symptoms did not include sadness and cry. So they worried and considered the symptoms were a disease. Participants felt inferior because they had different symptoms with their peers, as a result, one participant preferred to have male friends, like a statement of participants below:

"ya....gak pake nangis menangis gitu"; "minder sih..., sama perempuanperempuan...biasanya dikantin banyak ngobrol gosip gitu, iya sekarang komunikasinya sering banyak ma cowok, emang enak sama cowok sih...".

("Yes .... normal menstrual if without cry"; "feel not confident with women's classmates ... usually often talking so much ... so, I prefer to talk with boys to girls, feel more enjoy with them...")

“....kaget!......gak tau itu apa kirain apa.... terus pas pulang pulang.....nangis" ("....shocked!......I didn't know about this..I thought any something and then I was at home ...cried")

“...ya takut kalo penyakit gitu”

("..i'm afraid if this is a disease")

\section{DISCUSSION}


Positive perception arises because participants' perceived that the symptoms were a habit and normal for women. Adolescents accepted that the symptoms of PMDD as a natural phenomenon of women. The results of this study support research conducted by Sveinsdottir et.al. (2002), women accepted the phenomenon of PMS as a normal phenomenon.

This study finding also in line with a research conducted by Rapkin \& Mikacich (2013), 69.2\% of the 393 adolescents who experienced premenstrual symptoms thought that the symptoms were a normal phenomenon in women, none of them assumed as a serious problem, despite it disrupted their daily activities such as school activities, social relationships, and daily routine during the luteal phase.

Negative perception arises as participants perceived that the symptom was excessive, not usual condition or abnormal thus making some of them felt not confident or inferior with their selves because they felt different from their peers. Another study conducted by Morrison et al. (2010) in 136 women, found that 13\% of women had negatively judgment to the symptom of PMDD as a curse, and $32 \%$ of them viewed as a disease or disorder. However, $83 \%$ participants said that menstruation is a natural process for women. Their reasons for judgment to the symptoms of PMDD was negative because they had menstrual bleeding from moderate up to heavy bleeding and long menstrual period. Their assumption of the normal menstruation is marked by mild bleeding and short menstrual period.

\section{CONCLUSION}

Two themes identified in this study which are positive and negative perception. Nurses and other healthcare providers at healthcare institutions are expected to be more actively participating to provide various kinds of health education especially about PMDD symptoms in adolescents. This study has not described the specific experience related to PMDD symptoms. So hopefully this research can be a consideration for further researchers related to symptoms of PMDD more depth or other menstrual disorders.

\section{REFERENCES}


Bigg, W.S., and Demuth, R.H. (2011). Premenstrual Syndrome and Prementrual Dysphoric Disorder. American Family Physician ; 84 (8).

Delara, M., Ghofranipour, F., Azadfallah, P., Tavafian, S.S., Kazemnejad, A., and Montazeri, A. (2012). Health related Quality of Life Among Adolescents with Premenstrual Disorders: A Cross Sectional Study. Health and Quality of Life Outcomes; 10 (1).

Hapsari, Elsi D., Mantani, Y., and Matsuo, H. (2006). The Prevalence of Premenstrual Dysphoric Disorder and Its Modulation by Lifestyle and Psychological Factors in High School Students. Bulletin of Health Sciences Kobe ; 22: 19-28.

Holloway, I., and Wheeler, S. (2010). Qualitative Research in Nursing and Healthcare. $3^{\text {th }}$ Edition. USA: Wiley-Blackwell. 2010.

Jarrah, S.S., and Kamel, A.A. (2012). Attitudes and Practice of S chool- Aged Girls Towards Menstruation. International Journal of Nursing Practice:18: 308-315.

Perry, S.E., Hockenberry, M.J., Lowdermilk, D.L., and Wilson, (2010) D. Maternal Child Nursing Care. $4^{\text {th }}$ edition. Missouri: MOSBY Elsevier.

Pakmehr, S., and Hagh-Shenas. (2011).Work Stress, Premenstrual Syndrome and Dysphoric Disorde: Are There Any Associations?.Iranian Red Crescent Medical Journal: 13.

Sveinsdottir, H., Lundman, B., and Norberg, A. (2002). Whose voice?whose experiences?women's qualitative accounts of general and private discussion of premenstrual syndrome. Nordic College of Caring Sciences;16: 414-423.

Rapkin, A.J., and Winer, S.A. (2009). Prementrual Syndrome and Premenstrual Dysphoric Disorder: Quality of Life and Burden of Illness. Expert Review Pharmacoeconomics Outcomes; 9 (2): 157-170.

Omu, F.E., Al-Marzouk, R., Delles, H., Oranye, N.O., and Omu, A.E. (2011). Premenstrual Dysphoric Disorder: Prevalence and Effects on Nursing students's academic performance and clinical training in Kuwait. Journal of Clinical Nursing; 20 (2915-2923).

Yang, M., Wallenstein, G., Hagan, M., Guo, A., Chang, J., and Kornstein, S. (2008). Burden of Premenstrual Dysphoric Disorder on Health-Related Quality of Life. Journal of Women's Health; 17 (1). 
Dewi Marfuah: Adolescents’ Ambivalence of Premenstrual Dysphoric Disorder (PMDD) 